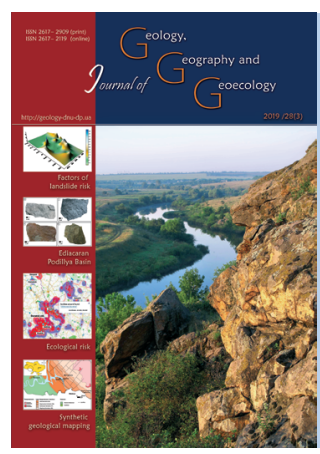

Journal of Geology.

ISSN 2617-2909 (print)

Geography and

Geoecology

ISSN 2617-2119 (online)

Mashika H. V.

Journal home page: geology-dnu-dp.ua

Journ.Geol.Geograph.

Geology,

28(3), 475-486.

doi: $10.15421 / 111943$

\title{
Economic and geographical aspects of research into the economic potential of the Carpathian region
}

\author{
Mashika Hanna Vasylivna \\ Mykachevo State University, Mykachevo,Ukraine, mashika.g.v@i.ua
}

Received: 08.02.2019

Received in revised form: 18.02 .2019

Accepted: 14.03.2019

Abstract. The article clarifies that during the administrative and territorial reform in Ukraine an important role is played by the capacity of the territory and the efficiency of the economic -managerial operations, in the assessment of which the most significant indicator is the availability of economic potential of the territory. Regarding the natural and geographical aspects of the research of the territorial structure of the economic complex of the Carpathian region, this region has a substantial natural capacity for the development of economic potential. Therefore, this region has all the preconditions to become one of the most developed regions of Ukraine. There are different classifications of the resources which make up and form the natural potential of the region. One of them is the allocation of resources according to the production spheres and industries where they can be applied, such as agricultural; non-productive; industrial. When it comes to the economic aspects of the research on the territorial structure of the economic complex of the Carpathian region, their dynamics are determined by the demographic situation of the region. Their dynamics are characterized by decrease in the rural population, cutback of the growth rate of the rural population, its ageing (individuals over 70 years old take up the largest share in the general age structure of the population), and emigration of young people, which is observed alongside some positive tendencies in birth rate increase. Accordingly, the processes of labour force ageing negatively affect the informational enhancement of all spheres of economy functioning throughout the region. This is connected with the failure of the region to embrace the state-of-the-art technologies. Such a demographic situation has influenced the structure of the labour market, the formation of which is accompanied by the release of a significant amount of labour resources and the deterioration of the situation in occupation and employment. At the same time, the freeing up of border crossing has contributed to the mass emigration of villagers to neighbouring countries seeking for employment. This has happened as a consequence of the economic processes that have taken place in the region, which are: high unemployment, prevalence of part-time jobs, and low wages. When we take into account the available and favourable natural, economic, scientific and technical factors in the development of the economic complex in the region, its historical and geographical inheritance, it is clear that strategic goals should include reasonable use of natural, material and technical, labour and intellectual capacities, and creation of an effective economic system. Such a system has to be able to provide material needs of various industries of the territorial economy and increase the level of environmental safety in the region. Herewith, based on the received data on the socio-economic and ecological status, we have identified are some main priorities for developing the Carpathian region. These priorities are as follows: development of tourist and recreational, agricultural and industrial, and forestry complexes; development of the non-productive sphere (especially in the area of mountainous territories); increase of the economic development of the Carpathian region; protecting the environment and raising the responsibility for the irrational use of natural resources and large amounts of pollutant emissions into the environment; taking measures to restore the historical and cultural traditions of the Carpathian region.

Key words: territorial structure, economy, economic complex, economic potential, the Carpathian region.

\section{Економіко-географічні аспекти дослідження господарського потенціалу Карпатського регіону}

Г.В. Машіка

Мукачівський державний університет, Мукачево, Украӥна, mashika.g.v@i.ua

Анотація. У статті з'ясовано, що в Україні під час проведення адміністративно-територіальної реформи важливу роль відіграє дієздатність території та ефективність функціонування господарства, при оцінюванні чого найважливішим по- 
казником є наявність господарського потенціалу території. Що стосується природно-географічних аспектів дослідження територіальної структури господарського комплексу Карпатського регіону, то він володіє значним природним потенціалом для розвитку господарського потенціалу, а отже має всі передумови, щоб увійти до числа найбільш розвинених регіонів України у цьому відношенні. Існують різні класифікації ресурсів, що входять і утворюють природний потенціал регіону. Одним 3 них є розподіл ресурсів відповідно до сфер і галузей виробництва, де вони можуть бути застосовані: сільськогосподарські; невиробничі; промислові. Що стосується економічних аспектів дослідження територіальної структури господарського комплексу Карпатського регіону, то їх динаміка зумовлена демографічною ситуацією регіону, яка характеризується зменшенням сільського населення, скорочення темпів приросту сільського населення, його старінням (особи, віком понад 70 років становлять найбільшу частку у загальній структурі населення), еміграцією молоді, деякими позитивними моментами щодо збільшення народжуваності. Відповідно, процеси старіння трудових ресурсів негативно впливають на інформатизацію усіх сфер функціонування економіки регіону у зв'язку з неспроможністю останніх до освоєння новітніх технологій. Така демографічна ситуація вплинула на структуру ринку праці, формування якого супроводжується вивільненням значної кількості трудових ресурсів та погіршенням ситуації у сфері зайнятості та працевлаштування. У той же час, вільний перетин кордону сприяв масовій еміграції селян до сусідніх держав з метою працевлаштування. Це стало наслідком економічних процесів, які відбувалися у регіоні: високий рівень безробіття, неповна зайнятість, низький рівень оплати праці. Зважаючи на наявні в регіоні сприятливі природні, економічні, наукові та технічні фактори розвитку господарського комплексу, його історична та географічна ретроспектива, стратегічні цілі включають оптимальне використання природного, матеріально-технічного, трудового та інтелектуального потенціалів, створення ефективної економічної системи, яка здатна забезпечити матеріальні потреби різних галузей територіальної економіки та підвищення рівня екологічної безпеки регіону. При цьому, спираючись на отримані дані щодо соціально-економічного та екологічного стану, серед основних пріоритетів розвитку Карпатського регіону є розробка туристично-рекреаційного, агропромислового, лісопромислового комплексів, розвиток невиробничої сфери (особливо на території гірських територій), підвищення економічного розвитку Карпатського регіону, охорона навколишнього середовища та підвищення відповідальності за нераціональне використання природних ресурсів та великі обсяги викидів забруднюючих речових у навколишнє середовище, здійснення заходів щодо відновлення історико-культурних традицій Карпатського краю.

Ключові слова: територіальна структура, господарство, господарський комплекс, господарський потенціал, Карпатський регіон.

Introduction. In the modern world, the capacity of certain territories is one of the most important pledges of the successful prosperity of a country. So in Ukraine during the process of administrative and territorial reform, a crucial important role is played by the capacity of the territory and the efficiency of the economy, in the assessment of which the most important indicator is the availability of the economic potential of the territory.

For the recent period of time, socio-economic and political transformations in Ukraine and the country's desire for full integration into the world's economic community have facilitated some positive changes. First of all, they contribute to the formation of new ways and mechanisms of national development, and influence on the development of industrial relations in various spheres of economic activity, and on the assessment of the role of resource factors in production and provision of social development and well-being. Regarding this, a special approach is required for such a sphere of vital importance to society as use of natural resources.

The modern global concept of socio-economic development, on which the future of mankind is oriented, along with social and economic factors of social development, distinguishes as primary, the natural component and relates the sustainable development of civilization to the use of a number of necessary measures and restrictions in order to avoid irreversible destructive changes in the natural environment. This requires careful use of natural resources. Considering this, the main purpose of the article is to analyze the economic and geographic aspects of the study of the economic potential of the Carpathian region.

Material and methods. In the course of our research, economic and geographic aspects of the study of economic potential of the Carpathian region have been investigated. The information base of the study was provided by monographs, scientific and analytical publications by domestic and foreign authors; official data of the State Statistics Service of Ukraine and regional statistical services of Lviv, Ivano-Frankivsk, Chernivtsi and Transcarpathian regions, etc. The study used both general scientific (systematic approach, structural analysis and synthesis, literary, mathematical and statistical, and historical methods), as well as special methods (comparative and geographical, classification and typology, regionalism, zoning, and expeditionary method).

Results and their analysis. The analysis of the productive forces of the Carpathian region and their development through the prism of the current economic and geographical situation allows one to form a real assessment of the effectiveness and prospects of development of the entire territorial structure of the economic complex. Despite the economic achievements of previous years, it should be noted that irrational and sometimes foolish economic policy and false management actions have 
led to the formation of a non-vital and deformed economic system in the region that has lost its social attractiveness and economic efficiency, and poses an environmental threat to the region. This has led to the accumulation of a range of social, economic and environmental issues that require immediate solution. The analysis of the socio-economic situation in the region according to the criteria of present day and the search for optimal ways of sustainable development requires attention to be paid to negative phenomena that have become relevant in the recent years. As O. Olshanska, M. Fashchevskyi, and I. Bilokon point out, the territorial structure of the economy can be considered as a means of reflecting the interconnection of various elements of the structure of industry, in which an inseparable system of natural resources, society, production spheres, service, and infrastructure is treated as a complex of branches of social life (Ol'chans'ka, Fachevs'kyj, Bilokon ', 2009) (see Figure 1). This interpretation overlaps with the notion of "branch structure", which is determined by the ratio by type of economic activity.

We agree with O. Dobrovolska that the territorial structure of the economy of the region includes territorial branch subsystems, such as industrial, agricultural, transport, etc. According to $\mathrm{O}$. the ecology. These are the means of the territorial structure of the economy and the outspread of society, along with means of natural resource potential, economic and geographical position and geopolitical location, socio-economic regional indicator and product competitiveness, which are indicators for determining the geo-economic potential of the state (Maniv, Luts'kyj, Maniv, 2007).

Thus, the territorial structure should be understood as a set of territorial relations between individual production facilities. It should also be noted that the level of development of territorial structures has a substantial impact on the functioning of the economic complex of the country as a whole.

Comprehensive economic development of the region is based on the consolidation of marketindustries of national importance, industries that provide for the needs of the population and the development of leading industries and sectoral infrastructure. A complex approach to the development of a regional economy involves the formation of stable economic and inter-branch links, which will also facilitate the development of the sphere of services of the territorial complex.

All regions, economic regions, have specific natural and resourceful potential and their indigenous

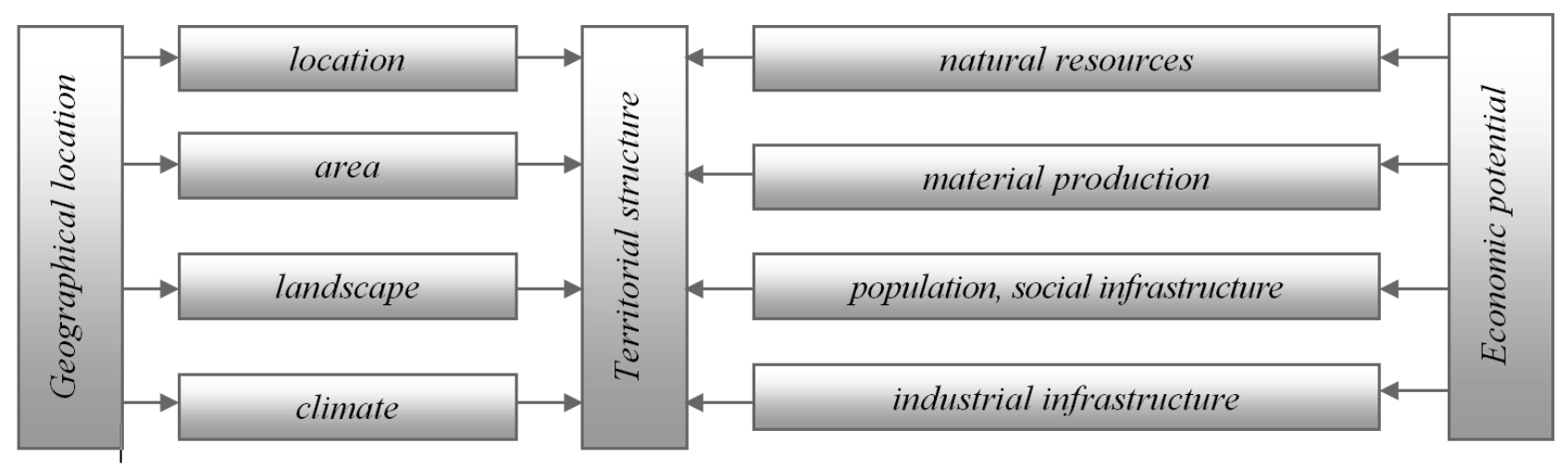

Fig. 1.Scheme of the influence of geographical position and economic potential on the territorial structure of the economy*

*-the author's own development

Dobrovolska, the territorial structure of the economy of the region involves the dimensional organization of various types of production on its territory, with the establishment of close interconnections between the economic centre (s) of the region and the areas (Dobrovol'skaia, 2007).

Territorial structure arises, based on the territorial division, integration processes of labour and specialized mechanisms of the economy. This concept combines different types of productive means and the distribution of human resources, considering social and territorial development and the state of features of the economy and social factors, which are prominent aspects in establishing their economic profile. Regions should be understood in terms of economic unity, territorial economic organization, the main milestones of which are market specialization (Hajdenko, 2018) is.

With regard to the natural and geographical aspects of the study of the territorial structure of the economic complex of the Carpathian region, this region has a significant natural potential, and therefore has all the prerequisites to become one of the most developed regions of Ukraine in this respect. There are different 
classifications of resources that are included in and form the natural potential of the region. One of them is the division of resources according to the spheres and industries where they can be applied: agricultural, which includes all the resources needed and involved in agriculture, such as soil, land, natural and climatic resources; non-productive, which are resources not involved in economic activity, but necessary for the normal functioning of society; industrial, which are a set of resources involved in economic activity and industrial production.

In the context of the analysis of the economic and geographic aspects of the study of the territorial structure of the economic complex of the Carpathian region, it is worth noting that it includes four administrative regions: Lviv, Transcarpathia, IvanoFrankivsk and Chernivtsi (see Figure 2). Let's consider the features of the natural and geographical location of each of the regions more rigorously (Dovhan ', 2005):

1. Lviv region. It is located in the western part of the country. The territory is 21.8 thousand square kilometres. The area of Verkhniobusk Lowland, located in the north, is marshy in patches; the Podillyan Upland and Roztochchya are located in the centre, in the south there are the Prydnistrovskyi depression, foothills and the Ukrainian Carpathians, which include the Beskyds and the Vododilni ranges. There are significant deposits of natural resources in the region, including oil, natural gas (in the PreCarpathian oil and gas region), coal reserves (Lviv and Volyn coal basin), potassium and rock salt (Stebnyk potassium salts deposit), sulphur, ozocerite, and building materials. There are several wells with mineral elements, which are the basis for the establishment and operation of spa health resorts (in particular Morshyn and Truskavets). The area is marked by a moderately continental climate, warm summer, and there are frequent thaws in winter. The mountainous climate has a more severe character. In January, on the Podillyan Uplands, the thermometer reaches $-4.7^{\circ} \mathrm{C}$, in the Pre-Carpathian territories -6.1 ${ }^{\circ} \mathrm{C}$, the Carpathians have a temperature of $-6.6^{\circ} \mathrm{C}$; in July the temperatures for these areas are $+18.7^{\circ} \mathrm{C}$,

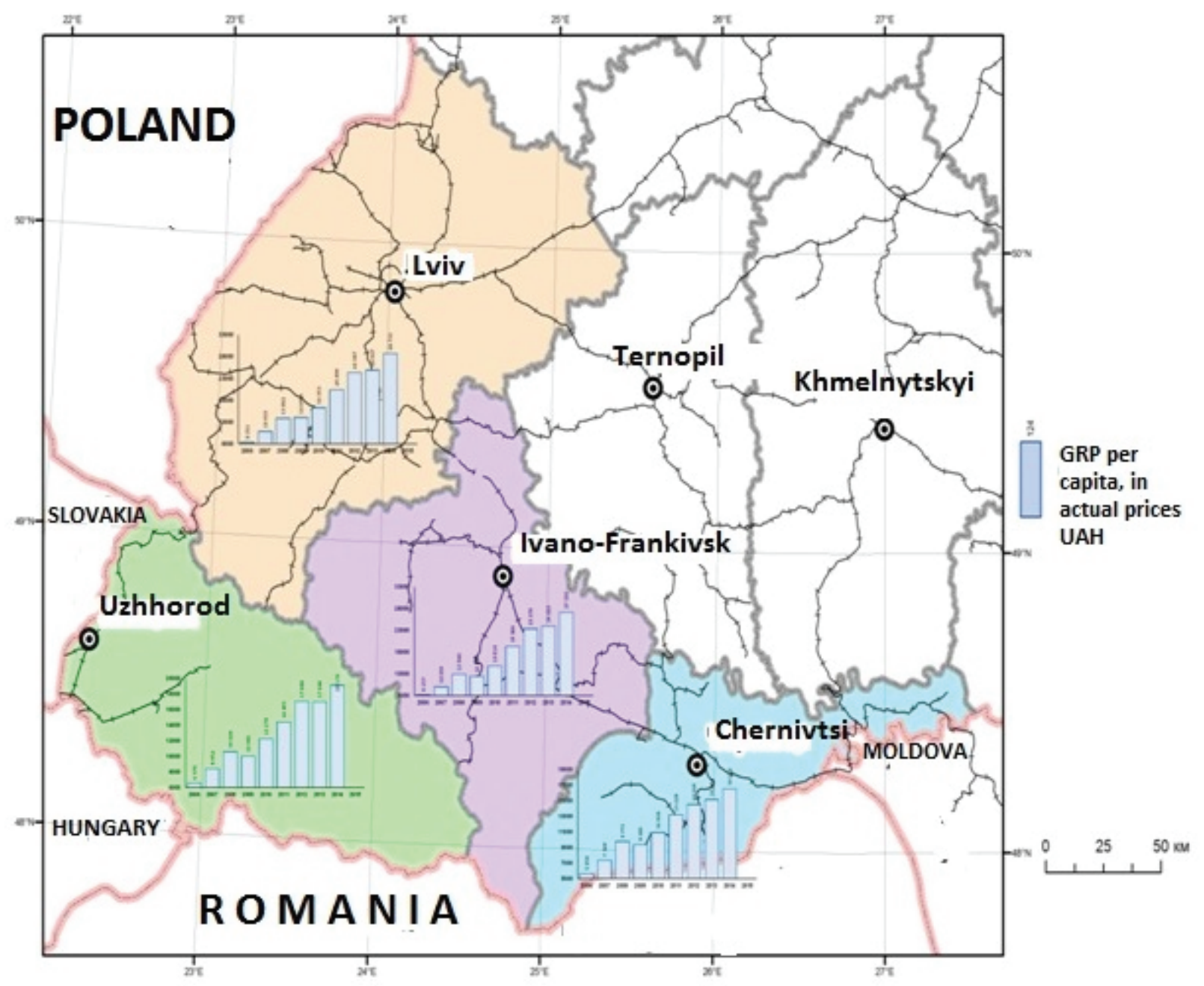

Fig. 2. Territorial structure of the Carpathian region*

*- by materials (Dovhan' H. D., 2005) 
$+18^{\circ} \mathrm{C},+16^{\circ} \mathrm{C}$, respectively. The precipitation on the territory of the Podillyan Uplands is $641-742$, in Pre-Carpathians 685-773, in the mountainous area it is up to $1000 \mathrm{~mm}$ per year. Most of all, this indicator rises during summer .

2. Transcarpathian region. It is located in the western part of the state. The territory is 12.8 thousand square kilometres. Transcarpathian region has two types of relief: mountainous (Ukrainian Carpathians) and flat (Transcarpathian lowland). The mountainous area occupies approximately $4 / 5$ of the area. The ranges of the Carpathian Mountains extend from the northwest to the southeast. The altitude of the Transcarpathian lowland reaches $105-120 \mathrm{~m}$ and this tract tilts slightly from the mountain ranges to the Tysa River. The area is rich in minerals; there are deposits of rock salt, brown coal, mercury ore, alum stones, gold, polymetallic ores, tuffs, dolomites, pearl stones, bentonite clays, and the like. There are also large concentrations of mineral water springs here. This area has a moderately continental climate, with short and mild winters in the lowland and warm summers. In January, the temperature reaches from -2 to $-3{ }^{\circ} \mathrm{C}$, in July on average $+19 \ldots+21^{\circ} \mathrm{C}$. In the upper part of the area, the temperature in the summer is quite cool: $+9 \ldots+13^{\circ} \mathrm{C}$ in July, the winter lasts a long time and is marked by a relatively low temperature: in January $-5 \ldots-9^{\circ} \mathrm{C}$. The amount of precipitation depends on the height and ranges from 642 to $1411 \mathrm{~mm}$.

3. Ivano-Frankivsk region. It is located in the northern part of the state, it occupies the foothills and mountainous parts of the Carpathian Mountains located in Ukraine. The territory is 13.9 thousand $\mathrm{km} 2$. The region has three types of relief: the north-eastern part is flat (the surface of the Podillya Upland), the middle part covers the foothills (the Pre-Carpathians), and the south-western part is mountainous (the Ukrainian Carpathians). The Carpathian region has a system of river valleys. About half of the region's territory is occupied by the Carpathian Mountains, in particular the mountainous ranges of the Horhan, the Pokuttya and Bukovyna Carpathians, the Hrynyavy and Chyvchyny Mountains, and Chornohora, where the highest point in Ukraine, Hoverla, is situated. Its height is $2,061 \mathrm{~m}$. The reserves of minerals are represented by oil and natural gas (in the Pre-Carpathian oil and gas region), brown coal, ozocerite, large reserves of sulphur and rock and potassium salt, gypsum, slate, phosphorites, various building materials and mineral water wells . It is an area with a moderately continental climate, mild winters, warm summers in the plains and foothills. The average temperature in January is $-4 \ldots-4.5^{\circ} \mathrm{C}$, and in July is from +18 to $+19.5^{\circ}$
C. In the mountainous area, the temperature is lower: $-6^{\circ} \mathrm{C}$ in January, $+16^{\circ} \mathrm{C}$ in July. The precipitation reaches from 600 to $800 \mathrm{~mm}$ in the Carpathian region, to $1,400 \mathrm{~mm}$ in the mountains.

4. Chernivtsi region. It is located in the western part of the country in the Pre-Carpathian and Eastern Carpathian territory. It covers an area of 8.1 thousand square kilometres. In its south-western part there are the Carpathian Mountains, which are a series of ranges, placed in parallel, up to $1,400 \mathrm{~m}$ height.

To the north-east of the Carpathian Mountains, the foothills of the piedmont plain reach out. In the northern part of the territory, the Prut-Dnister riparian line lies along with the Khotyn Hill in its middle part. Here is the highest peak of the Ukrainian plains - Berda Mountain, reaching $515 \mathrm{~m}$ in height. There is a system of canyon-like valleys of rivers, ravines and gullies that dissect the local surface. In the western part you can find karst. Natural resources are represented by phosphorites, gypsum, quartz, glauconitic sands, clay, limestone, marble, graphite, and brown coal. There are also supplies of mineral wells and therapeutic mud. The territory is characterised by a moderately continental climate: cool and wet in the summer, moderately cold in winter. In January, in the lowlands the temperature is from -4.8 to $-5.0^{\circ} \mathrm{C}$, in the foothills $-4.8 \ldots-5.5^{\circ} \mathrm{C}$, in the mountains from -6 to $-10^{\circ} \mathrm{C}$, in July $+18.8 \ldots+19.5^{\circ} \mathrm{C},+16.2 \ldots+19.0$ ${ }^{\circ} \mathrm{C},+13 \ldots+16{ }^{\circ} \mathrm{C}$, respectively. The rate of precipitation is as follows: $500-600 \mathrm{~mm}$ - in the plains, $800-$ $1200 \mathrm{~mm}$ - in mountainous areas, precipitation falls mainly in the summer.

The Carpathian region of Ukraine covers an area of 56,607 square kilometers, which corresponds to $9.4 \%$ of the territory of the country. The abovementioned Transcarpathian, Ivano-Frankivsk, Lviv and Chernivtsi regions belong to it. This is justly the "natural pearl" of our country, because its territory includes $22 \%$ of the nation's forests, $26 \%$ of its nature reserves, $36 \%$ of its water resources of river flows, $42 \%$ of its exclusive and rare underground mineral water. Despite this, it has its own negative conditions related to the geography of the region: low amount of arable land, poor road and transport capability, frequent adverse hydrological phenomena and climatic conditions that complicate farming. This has ensured that the level of economic development favours the plains at the expense of the mountainous areas. This, in the conditions of an open market system, in turn leads to depopulation tendencies, and poses a risk of the disappearance of the distinctive ethno-cultural system of the mountains (Kravtsiv V.S., 2013). The Carpathian region of Ukraine is significantly exposed 
to adverse environmental phenomena, such as threatening and catastrophic floods, soil erosion, surface and underground water pollution, damage caused by strong wind, damage to forests from diseases and pests (Kravtsiv, 2013).

In the Carpathian region, there is a general tendency to reduction of emissions of harmful substances in 2017 compared to 2010. In our opinion, the reason for this is that the scope of production is decreasing, the sources of emissions are eliminated, individual production units have stopped operating, and investments have fallen. All of that leads to the fact that the emissions of the enterprises correspond to the normative ones or are lower than them. However, for the last two years the situation has been worsening (see Figure 3).

Considering this, one can track a small increase ineffectiveness of obsolete gas-cleaning systems is obvious at asphalt and concrete production enterprises, in particular, at plants run by the Transcarpathian regional road service and the heating networks of Mukachevo, Berehovo, Vynohradiv, Khust.

Inappropriate equipment is also installed at boiler-houses of the Ministry of Transport and Communications of Ukraine. In recent years, it has been possible to notice a significant increase in the number of vehicles and the number of gas stations, which also substantially pollute the atmosphere (Rehional'na dopovid 'pro stan navkolyshn'oho pryrodnoho sererdovyscha Zakarpats'koi oblasti).

The level of pollution of the atmosphere significantly influences the well-being of city residents, leading to the development of chronic diseases of the cardiovascular, nervous and respiratory systems,

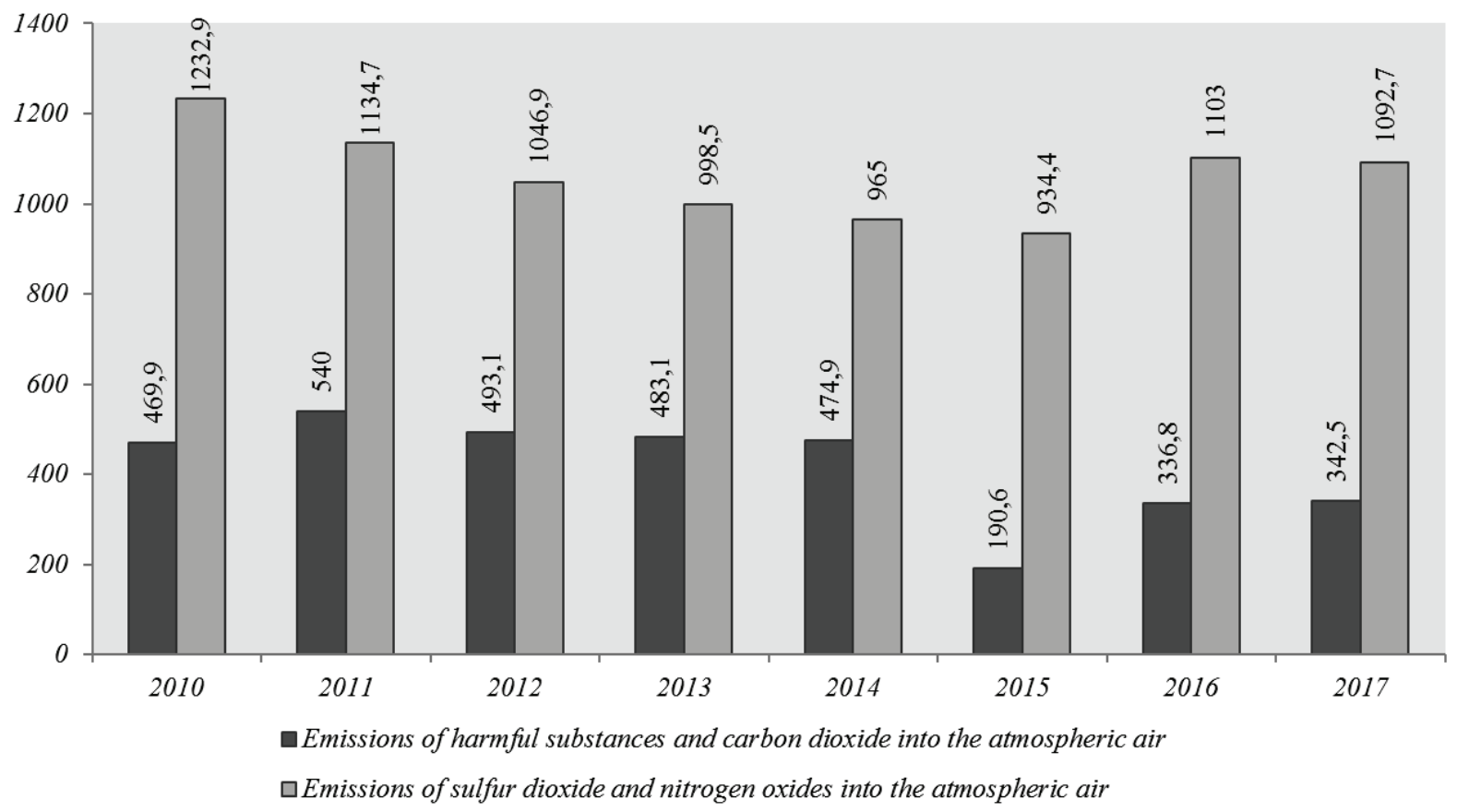

Fig. 3. Dynamics of indicators of emissions of harmful substances into the atmosphere of the Carpathian region during 20102017

*- developed by the author on the basis of statistical data of the regions of the Carpathian region

in the number of substances that have been emitted into the atmosphere by stationary sources that pollute the air. The increase in the number of such cases was possible due to the main factors of pollution; in particular, we observe similar activity near OJSC "Zakarpathaz" and gas pipelines of UMG "PrykarpattransHaz", which is the Transcarpathian regional linear production organisation for the main gas pipelines. Such incidents depended on the volume of gas pumped by these producers. One of the main causes of emissions into the air is obsolete technical equipment, repairs and prophylactic measures at the stations with compressor equipment.The worsening of the blood state, development of allergic reactions, etc. Most of all, this is felt by people living near highways which are characterized by heavy traffic. Here the level of contamination is many times higher than the level of harmful emissions in places without such traffic, or in the park zones. Cars have the ability not only to pollute the air, but also to have a negative acoustic effect. According to researchers, noise pollution contributes to the exacerbation of diseases of the cardiovascular system, which causes the bulk of deaths among city residents (Rehional'na dopovid 'pro stan navkolyshn'oho pryrodnoho sererdovyscha u L'vivs'kij oblasti). 
Among the main sources of air pollution in Ivano-Frankivsk region, it is crucial to point out entrepreneurial activity directed at the production and distribution of electricity, gas and water resources (89.2\% of total regional scopes). In this context, one should note businesses in the towns of Burshtyn and Kalush, and other settlements of Dolyna, Nadvirna and Bohorodchany districts. To a large extent, harmful effects on atmospheric air are caused by the spread of pollutants from central European countries; regrettably the absence of a network of control points precludes the possibility of an accurate assessment of the extent of transboundary pollution and the scale of its impact on the atmospheric air of the region (Rehional'na dopovid 'pro stan navkolyshn'oho pryrodnoho sererdovyscha $v$ Ivano-Frankivsk region).

In recent years, due to the decline of the production industry and the replacement of solid fuel with gaseous fuel, in Chernivtsi region, it has been possible to observe a slight decrease in the level of pollution of atmospheric air. It is worth mentioning that on the territory of the Chernivtsi region, the choice of modern highly-advanced and economical heating devices is becoming more and more popular among enterprises. Such facilities for heating buildings and providing for other technological needs unconditionally reduce the harmful effects of emissions and help maintain the state of the atmospheric air (Rehional'na dopovid 'pro stan navkolyshn'oho pryrodnoho sererdovyscha v Chernivets'kij oblasti).

Researchers state the fact of the development of compensatory mechanisms for the differences between integrated farms of the regions by a regional political system. These involve the creation of special subsidies and preferential loans, which will stimulate investment activity and its development in regions with an under-developed economy. Thus, lagging regions have a chance to step forward in their development, while modern leading regions may lose this status. It follows that such processes have the chance to gain momentum and require constant state attention. If this is not provided, regions with depressive symptoms may stop their development completely (Hajdenko).

Therefore, realization of the state tasks and goals, i.e. carrying out of economic, social, demographic, scientific and technical and ecological policies on the regional level, has a significant impact on the development of the territorial structure of the economic complex of the region (area, territory). It should be outlined that the influence of regional policy on the development of the economic complex of the region is performed through regional planning, forecasting and programming.

Regarding the economic aspects of the study of the territorial structure of the economic complex of the Carpathian region, their dynamics are determined by the demographic situation of the region, which is characterized by a decrease in the rural population, a decrease in the growth rate of the rural population, its ageing (individuals over 70 years old represent the largest share in the general age structure of the population), emigration of young people, though an increasing birth rate provides a positive tendency (see Table 1). The combination of these facts is confirmed by the fact that there is a gradual extinction of labour resources in this territory and, accordingly, deterioration in the professional training of the existing population. This is explained by the fact that the processes of ageing of the labour force negatively affect the informatisation of all spheres of functioning of the region in connection with the failure of the latter to master the state-of-the-art technologies.

In accordance with the above data, we can conclude that in all regions of the Carpathian region, apart from Lviv, the share of rural population prevails. In particular, the rural population prevails in the population structure of Transcarpathian region and is growing at a higher pace. In general, the population of the region has grown by $1.07 \%$, while the population of such regions as Lviv, IvanoFrankivsk has decreased by $0.78 \%$ and $0.23 \%$ respectively, while Chernivtsi it has increased by only $0.25 \%$. Due to this, the population of the Carpathian region has declined by $0.13 \%$ since 2010 up to 2018 . Regarding the structure, city residents predominate in Lviv region, in Ivano-Frankivsk region there are fewer urban residents, and in Chernivtsi there are also fewer city residents than rural inhabitants. The urban population in Lviv region has decreased by $0.37 \%$, the number of inhabitants of villages - by $1.41 \%$, and in Ivano-Frankivsk and Chernivtsi regions - by $1.66 \%$ and $1.69 \%$ respectively. This has provided a reduction of the rural population of the Carpathian region by $0.83 \%$ from 2010 to 2018 .

Such a demographic situation has affected the structure of the labour market, the formation of which is accompanied by the release of a significant amount of labour resources and the deterioration of the situation in occupation and employment. At the same time, the liberalisation of border crossing has contributed to the mass emigration of villagers to neighbouring states with the purpose of employment. This has become a consequence of the economic processes that are taking place in the region, which are high unemployment, predominance of part-time jobs, and low wages.

The general indicator that determines the efficiency of functioning of the region's economy is 
Table 1. The dynamics of demographic indicators of the Carpathian region population during 2010-2018, thsd persons*

\begin{tabular}{|c|c|c|c|c|c|c|c|c|c|c|}
\hline \multirow{2}{*}{ Indicator } & \multicolumn{9}{|c|}{ Year } & \multirow{2}{*}{$\begin{array}{c}\text { Deviation } \\
2018-2010+/-\end{array}$} \\
\hline & 2010 & 2011 & 2012 & 2013 & 2014 & 2015 & 2016 & 2017 & 2018 & \\
\hline \multicolumn{11}{|c|}{ Transcarpathian Region } \\
\hline Current Population: & 1244.8 & 1247.4 & 1250.7 & 1254.4 & 1256.9 & 1259.6 & 1259.2 & 1258.8 & 1258.1 & 13.3 \\
\hline Urban Population & 462.6 & 463.8 & 465.2 & 466.4 & 466.9 & 467.3 & 467 & 465.5 & 465.5 & 2.9 \\
\hline Rural Population & 782.2 & 783.6 & 785.5 & 788 & 790 & 792.3 & 792.2 & 793.3 & 792.6 & 10.4 \\
\hline \multicolumn{11}{|c|}{ Lviv Region } \\
\hline Current Population: & 2549.6 & 2544.7 & 2540.9 & 2540.7 & 2538.4 & 2537.7 & 2534.2 & 2534.0 & 2529.6 & -20 \\
\hline Urban Population & 1547.9 & 1546.4 & 1544.8 & 1546,1 & 1545.8 & 1547.1 & 1544.9 & 1544.7 & 15421 & -5.8 \\
\hline Rural Population & 1001.6 & 998.2 & 996.1 & 994.5 & 992.5 & 990.7 & 989.3 & 989.3 & 987.5 & -14.1 \\
\hline \multicolumn{11}{|c|}{ Ivano-Frankivsk Region } \\
\hline Current Population: & 1380.7 & 1379.8 & 1380.1 & 1381.8 & 1382.1 & 1382.6 & 1382.4 & 1379.9 & 1377.5 & $-3,2$ \\
\hline Urban Population & 596.4 & 597.2 & 597.7 & 599.6 & 600.8 & 602.6 & 604.5 & 605.1 & 606.2 & 9.8 \\
\hline Rural Population & 784.3 & 782.6 & 782.4 & 782.2 & 781.3 & 780 & 777.9 & 774.8 & 771.3 & -13 \\
\hline \multicolumn{11}{|c|}{ Chernivtsi Region } \\
\hline Current Population: & 904.4 & 904.3 & 905.3 & 907.2 & 908.5 & 910 & 909.9 & 908.1 & 906.7 & 2.3 \\
\hline Urban Population & 379.3 & 381.1 & 383.1 & 385.7 & 388.2 & 390.3 & 391.8 & 391.1 & 390.5 & 11.2 \\
\hline Rural Population & 525.1 & 523.2 & 522.2 & 521.5 & 520.3 & 519.7 & 518.1 & 517 & 516.2 & -8.9 \\
\hline \multicolumn{11}{|c|}{ Carpathian Region } \\
\hline Current Population: & 6079.5 & 6076.2 & 6077 & 6084.1 & 6085.9 & 6089.9 & 6085.7 & 6080.8 & 6071.9 & -7.6 \\
\hline Urban Population & 2986.2 & 2988.5 & 2990.8 & 2997.8 & 3001.7 & 3007.3 & 3008.2 & 3006.4 & 3004.3 & 18.1 \\
\hline Rural Population & 3093.2 & 3087.6 & 3086.2 & 3086.2 & 3084.1 & 3082.7 & 3077.5 & 3074.4 & 3067.6 & -25.6 \\
\hline
\end{tabular}

*- developed by the author on the basis of statistical data of the regions of the Carpathian region

the gross regional product, which is defined as the sum of the gross value added of all types of economic activity, including net taxes on products (see Table 2).

The gross regional product of the Carpathian region has been increasing throughout the period of the entire investigation, but this dynamic cannot be called uniquely positive due to the devaluation of the national currency and inflationary processes. At the same time, GRP per capita is increasing, and the growth rate is slowing down with each year. The largest GRP has been produced in the Lviv region, in the second place is Ivano-Frankivsk region, further - Chernivtsi and Transcarpathian regions. This determines the share of GRP per capita in terms of areas. The growth rate of the Transcarpathian GRP has a multi-vector dynamic, but with each year the dynamic is positive. In the Lviv, Ivano-Frankivsk and Chernivtsi regions, there is the same trend of the GRP.

Therefore, the most important measures for the development of the economic complex of the Carpathian region should include the harmonization of the social sphere with the existing needs of the population. The important aspect of development is providing of conditions for the regular reproduction of the labour force through raising the living standards of the population, especially in villages. An equally important condition for achieving such a level of development of the socio-economic potential of the region is the harmonization of development both of society and the natural environment.

Geopolitics of the territory and special ecological conditions have influenced the creation of the territorial structure of the economic complex of the Carpathian region. The territorial structure of the economy of the region combines the location, spatial systems, the apparatus for the development of settlements, the infrastructure of society and production, and the interconnection of all types of economic activity, which has arisen on the basis of natural and mineral resources (Nahirna, 2009).

As we see, the basis of the economic complex of the Carpathian region is the production and distribution of electricity, gas and water - $25.6 \%$. In the context of the development of the processing industry, the main industries are machine-building, chemical and petrochemical industries, as well as 
Table 2. The dynamics of the gross regional product of the Carpathian region during 2010-2018*

\begin{tabular}{|c|c|c|c|c|c|c|c|c|c|c|}
\hline \multirow{2}{*}{ Indicator } & \multicolumn{9}{|c|}{ Year } & \multirow{2}{*}{$\begin{array}{c}\text { Deviation } \\
2018-2010+/-\end{array}$} \\
\hline & 2010 & 2011 & 2012 & 2013 & 2014 & 2015 & 2016 & 2017 & 2018 & \\
\hline \multicolumn{11}{|c|}{ Transcarpathian Region } \\
\hline $\begin{array}{c}\text { GRP total, in } \\
\text { actual prices, mln. } \\
\text { UAH }\end{array}$ & 15299 & 18054 & 21404 & 21400 & 24120 & 28952 & 32390 & - & - & - \\
\hline $\begin{array}{c}\text { GRP per capita, } \\
\text { in actual prices, } \\
\text { UAH }\end{array}$ & 12278 & 14455 & 17088 & 17044 & 19170 & 22989 & 25727 & - & - & - \\
\hline \multicolumn{11}{|c|}{ Lviv Region } \\
\hline $\begin{array}{c}\text { GRP total, in } \\
\text { actual prices, mln. } \\
\text { UAH }\end{array}$ & 41655 & 52103 & 61962 & 63329 & 72923 & 94690 & 114842 & - & - & - \\
\hline $\begin{array}{c}\text { GRP per capita, } \\
\text { in actual prices, } \\
\text { UAH }\end{array}$ & 16353 & 20490 & 24387 & 24937 & 28731 & 37338 & 45319 & - & - & - \\
\hline \multicolumn{11}{|c|}{ Ivano-Frankivsk Region } \\
\hline $\begin{array}{c}\text { GRP total, in } \\
\text { actual prices, mln. } \\
\text { UAH }\end{array}$ & 20446 & 26752 & 32286 & 33196 & 37643 & 45854 & 51404 & - & - & - \\
\hline $\begin{array}{c}\text { GRP per capita, } \\
\text { in actual prices, } \\
\text { UAH }\end{array}$ & 14814 & 19386 & 23379 & 24022 & 27232 & 33170 & 37220 & - & - & - \\
\hline \multicolumn{11}{|c|}{ Chernivtsi Region } \\
\hline $\begin{array}{c}\text { GRP total, in } \\
\text { actual prices, mln. } \\
\text { UAH }\end{array}$ & 9892 & 11969 & 13166 & 13757 & 15049 & 18506 & 21239 & - & - & - \\
\hline $\begin{array}{c}\text { GRP per capita, } \\
\text { in actual prices, } \\
\text { UAH }\end{array}$ & 10939 & 13228 & 14529 & 15154 & 16552 & 20338 & 23365 & - & - & - \\
\hline \multicolumn{11}{|c|}{ Carpathian Region } \\
\hline $\begin{array}{c}\text { GRP total, in } \\
\text { actual prices, mln. } \\
\text { UAH }\end{array}$ & 87292 & 108878 & 128818 & 131682 & 149735 & 188002 & 219875 & - & - & - \\
\hline
\end{tabular}

*-developed by the author on the basis of statistical data of the regions of the Carpathian region

the woodworking industry. What is more, important areas of development are agriculture, recreation and tourism.

The level of economic growth of all sectors of the economy enables consumer demand to be met and solves economic problems in the region. One of the largest spheres in the public production of the region is industry. The level of its development is an indicator of the economic status of the region, its territorial specialization and the scale of the region's participation in the territorial division of labour. In the process of formation of economic conditions, stipulated by the level of market development, industrial producers are constantly looking for ways to improve and increase the competitiveness of their own production under existing conditions.

The value of industrial products sold in the
Carpathian region increased in the 2010-2018 by $164,168,021$ thousand $\mathrm{UAH}$, in particular due to the growth of this indicator in all regions. However, the increase in industrial production indexes may indicate an increase in prices for industrial products with a slight increase in the scope of production or supply. In contrast to the overall trend, in the Transcarpathian region, the index of industrial production has declined by $29.1 \%$.

Having analysed a number of economic and geographical areas of the territorial structure of the economic complex of the Carpathian region, in our opinion, it is necessary to emphasize the importance of the problem of the current ecological situation, which is caused by numerous factors.

The main reasons for the deterioration of the ecology of the Carpathian region are the following: 
Table 3. Sectoral structure of industry in terms of the regions of the Carpathian region, $\%$ *

\begin{tabular}{|c|c|c|c|c|c|}
\hline Industry Sectors & Transcarpathian & Ivano-Frankivsk & Lviv & Chernivtsi & $\begin{array}{c}\text { Carpathian } \\
\text { region }\end{array}$ \\
\hline All industries & 100 & 100 & 100 & 100 & 100 \\
\hline Mining industry: total & 1.4 & 6.5 & 4.7 & 1.1 & 3.4 \\
\hline Including: mining of fuel and energy natural resources & 0.1 & 6.2 & 4.4 & - & 2.7 \\
\hline Production and distribution of electricity, gas and water & 15.9 & 35.9 & 19.0 & 31.6 & 25.6 \\
\hline Processing industries in total & 82.7 & 57.6 & 76.3 & 67.3 & 71.0 \\
\hline including metallurgical production & 0.6 & 1.2 & 4.4 & 5.8 & 3.0 \\
\hline Chemical and petrochemical & 7.2 & 9.0 & 7.8 & 6.7 & 7.7 \\
\hline Machine-building & 41.4 & 2.4 & 11.6 & 8.6 & 16.0 \\
\hline Woodworking & 4.6 & 9.2 & 3.2 & 3.5 & 5.1 \\
\hline Cellulose and paper production & 1.0 & 3.0 & 5.4 & 1.5 & 2.7 \\
\hline Manufacture of coke, refined petroleum products & - & 6.9 & 6.9 & - & 3.5 \\
\hline Consumer goods industry & 5.1 & 2.0 & 3.3 & 6.6 & 4.3 \\
\hline Food industry & 15.3 & 15.3 & 26.5 & 25.5 & 20.7 \\
\hline
\end{tabular}

*- developed by the author on the basis of (Nahirna, 2009)

Table 4. Dynamics of the value of sold industrial products (goods, services) of the Carpathian region during 2010-2018, ths. UAH*

\begin{tabular}{|c|c|c|c|c|c|c|c|c|c|c|}
\hline Indicator & 2010 & 2011 & 2012 & 2013 & 2014 & 2015 & 2016 & 2017 & 2018 & \multirow[t]{2}{*}{$\begin{array}{c}\text { Deviation } \\
2018- \\
2010+/-\end{array}$} \\
\hline \multicolumn{10}{|c|}{ Transcarpathian Region } & \\
\hline $\begin{array}{l}\text { Value of sold in- } \\
\text { dustrial products } \\
\text { (goods, services) }\end{array}$ & $\begin{array}{c}7,07 \\
9,125,7\end{array}$ & $\begin{array}{c}8,86 \\
6,443,7\end{array}$ & $\begin{array}{c}9,95 \\
6,782,1\end{array}$ & $\begin{array}{c}10,03 \\
5,856,7\end{array}$ & $\begin{array}{c}11,15 \\
3,268,7\end{array}$ & $\begin{array}{r}13,87 \\
2,542,6\end{array}$ & $184,718,622$ & $\begin{array}{c}22,39 \\
9,848,2\end{array}$ & $\begin{array}{r}25,23 \\
3,378,1\end{array}$ & $\begin{array}{l}18,15 \\
4,252\end{array}$ \\
\hline $\begin{array}{l}\text { Indices of indus- } \\
\text { trial products }\end{array}$ & 142,9 & 101,8 & 101,4 & 96,9 & 106,1 & 79,7 & 105,9 & 100,3 & 101,3 & $-41,6$ \\
\hline \multicolumn{11}{|c|}{ Lviv Region } \\
\hline $\begin{array}{l}\text { Value of sold in- } \\
\text { dustrial products } \\
\text { (goods, services) }\end{array}$ & $\begin{array}{c}25,65 \\
5,264, .9\end{array}$ & $\begin{array}{c}32,39 \\
2,240,1\end{array}$ & $\begin{array}{r}34,87 \\
3,983,9 \\
\end{array}$ & $\begin{array}{r}34,62 \\
0,468,3 \\
\end{array}$ & $\begin{array}{r}39,58 \\
4,498,4 \\
\end{array}$ & $\begin{array}{r}58,50 \\
1,981,4 \\
\end{array}$ & $72,385,789,9$ & $\begin{array}{c}91,45 \\
7,271,8\end{array}$ & $\begin{array}{r}92,87 \\
9,613,2\end{array}$ & $\begin{array}{l}67,22 \\
4,348 \\
\end{array}$ \\
\hline $\begin{array}{l}\text { Indices of indus- } \\
\text { trial products }\end{array}$ & - & - & - & 101,2 & 97,2 & 98,5 & 99,3 & 106,0 & 103,4 & - \\
\hline \multicolumn{11}{|c|}{ Ivano-Frankivsk Region } \\
\hline $\begin{array}{l}\text { Value of sold in- } \\
\text { dustrial products } \\
\text { (goods, services) }\end{array}$ & $\begin{array}{c}13,83 \\
7,621,1\end{array}$ & $\begin{array}{c}24,18 \\
7,656,4\end{array}$ & $\begin{array}{r}25,26 \\
8,815,4 \\
\end{array}$ & $\begin{array}{r}22,01 \\
4,433,7 \\
\end{array}$ & $\begin{array}{r}25,14 \\
2,777,5 \\
\end{array}$ & $\begin{array}{r}34,74 \\
1,880,0 \\
\end{array}$ & $37,267,619,4$ & $\begin{array}{c}48,83 \\
4,881,0\end{array}$ & $\begin{array}{r}49,91 \\
1,225,7 \\
\end{array}$ & $\begin{array}{l}36,07 \\
3,604 \\
\end{array}$ \\
\hline $\begin{array}{l}\text { Indices of indus- } \\
\text { trial products }\end{array}$ & - & - & - & 95,3 & 98,9 & 89,1 & 95,5 & 112,0 & 107,6 & - \\
\hline \multicolumn{11}{|c|}{ Chernivtsi Region } \\
\hline $\begin{array}{l}\text { Value of sold in- } \\
\text { dustrial products } \\
\text { (goods, services) }\end{array}$ & $\begin{array}{r}3,19 \\
2,600 \\
\end{array}$ & $\begin{array}{l}4,06 \\
7,200\end{array}$ & $\begin{array}{r}4,10 \\
8,800\end{array}$ & $\begin{array}{r}4,09 \\
9,700 \\
\end{array}$ & $\begin{array}{l}4,67 \\
6,000 \\
\end{array}$ & $\begin{array}{r}6,82 \\
4,300 \\
\end{array}$ & $\begin{array}{c}9,42 \\
5,542,3\end{array}$ & $\begin{array}{c}9,68 \\
5,532,1\end{array}$ & $\begin{array}{r}9,98 \\
1,425,3 \\
\end{array}$ & $\begin{array}{r}6,78 \\
8,825\end{array}$ \\
\hline $\begin{array}{l}\text { Indices of indus- } \\
\text { trial products }\end{array}$ & - & - & - & 103,7 & 92,9 & 98,3 & 96,9 & 106,7 & 105,5 & - \\
\hline \multicolumn{11}{|c|}{ Carpathian Region } \\
\hline $\begin{array}{l}\text { Value of sold in- } \\
\text { dustrial products } \\
\text { (goods, services) }\end{array}$ & $\begin{array}{l}13,83 \\
7,621 \\
\end{array}$ & $\begin{array}{l}60,11 \\
4,647 \\
\end{array}$ & $\begin{array}{r}70,59 \\
4,699 \\
\end{array}$ & $\begin{array}{r}70,95 \\
4,0 \\
\end{array}$ & $\begin{array}{r}73,89 \\
8,803 \\
\end{array}$ & $\begin{array}{l}90,15 \\
5,647 \\
\end{array}$ & $\begin{array}{r}137,55 \\
0,813 \\
\end{array}$ & $\begin{array}{r}172,37 \\
7,533 \\
\end{array}$ & $\begin{array}{r}178,00 \\
5,642 \\
\end{array}$ & $\begin{array}{l}164,16 \\
8,021 \\
\end{array}$ \\
\hline $\begin{array}{l}\text { Indices of indus- } \\
\text { trial products }\end{array}$ & - & - & - & 99,275 & 98,775 & 91,4 & 99,4 & 106,2 & 104.5 & - \\
\hline
\end{tabular}

*- developed by the author on the basis of statistical data of the regions of the Carpathian region 
the lack of a proper balance between certain economic and industrial sectors, ignorant and unsympathetic attitude to nature and ecology in general. This has led to intensive use of natural resources and deterioration of the state of environment. The latter is closely linked to the influence of pollution factors, which negatively affects the health of the population in general and children in particular. The deteriorating state of ecology plays a significant role in increasing mortality rates. Electricity related substances, concerning the sphere of chemical, mining, as well as the transport and food industries, cause the majority of harmful emissions in the Carpathian region (Maniv, Luts'kyj, Maniv, 2007).

The natural environment is characterized by the states of exhaustion and degradation, which may be caused by insufficient ecological justification of the use of natural resources, the development of new lands and mining, agricultural methods, etc. The same applies to damage to integral landscape surfaces, the ecologically unbalanced structure of agricultural land use, which is aimed at obtaining agricultural products, and frequently ignores the ecological capacity, erosion resistance and excessive ruin of the earth's surface. Other negative factors are unreasonable exploitation of forestry, neglect of the importance of forests for modern ecology (Chakhraiuk- Onofrej, Lakusta, 2011).

The use of water reserves can also be considered as extremely irrational and unprofitable. Moreover, their pollution can be defined by industrial and agricultural wastes. It is worth noting that the greatest damage to surface and underground waters is brought by settlements, farms for breeding animals and various complexes, since they usually do not have sewerage and cleaning systems (Maniv, Luts'kyj, Maniv, 2007).

The Carpathian region is the most dangerous in terms of natural phenomena, in particular, floods. The probability of the occurrence of this natural disaster today has a tendency of growth. Every year flooding damages all regions of the Carpathian region. On this basis, it can be argued that the main method of securing this region is to take measures for soil retention, strengthening dams and other structures, which serve protective functions (Chakhraiuk-Onofrej, Lakusta, 2011).

Consequently, for the Carpathian region, as well as for other regions of Ukraine, there are many problems in the development of economic potential. That is why it is necessary to conduct in-depth studies of the development of all strategically important industries of the region in order to eliminate the downsides and improve the structure of the economic potential of the
Carpathian region. The problems of the development of the territorial structure of the economic complex of the Carpathian region include socio-economic, institutional and natural and ecological. However, they all have complex solutions, the implementation of which can eliminate the problem or at least periodically will halt their negative action. At the same time, it is necessary to improve each industry of the manufacturing and non-productive sphere, introducing measures to improve their development, which in general would improve the development of the whole Carpathian region.

When we take into account the available and favourable natural, economic, scientific and technical factors in the development of the economic complex in the region, its historical and geographical heritage, strategic goals should include three aspects:

- reasonable use of natural, material and technical, labour and intellectual potentials;

- creation of an effective economic system, which is able to provide for the material needs of various industries of the territorial economy;

- increase the level of environmental safety in the region.

Herewith, based on the received data on the socio-economic and ecological status, there are some main priorities to develop the Carpathian region. These priorities are as follows:

- development of tourist and recreational, agricultural and industrial, and forestry complexes; development of the non-productive sphere (especially in the mountainous territories);

- increase the economic development of the Carpathian region;

- protecting the environment;

- raising the responsibility for the irrational use of natural resources and large amounts of pollutant emissions into the environment ;

- taking measures to restore historical and cultural traditions of the Carpathian region.

Conclusion. Summing up all of the above mentioned, we can conclude that the development of the economic complex in the Carpathian region depends on its natural and economic potential. Awareness of the significance of the development of the economic complex at the present stage of the socio-economic transformation of the economic mechanism which is taking place in our country, is the best way to improve the standard of living of the population. Emphasising the importance of the economic complex, it should be noted that it involves a variety of directions of development of market relations in our country, the study and implementation of which covers the widest 
range of problems, the solution of which is a priority task on the way to restructuring the socio-economic mechanism of functioning of the Ukrainian economy.

Increasing the level of development of the economic complex will help in solving the problems of employment, structural changes in the economy, the formation of a competitive environment and the middle class of owners, which would guarantee stability and democracy in the society. Therefore, it will be crucial to study the potential to ensure the wise use of the investment climate, social processes, and, as a consequence, raise the standard of living of the population of Ukraine.

\section{References}

Hajdenko S. M. 2018. Vplyv rehional'noi polityky na rozvytok hospodars'koho kompleksu[Influence of regional policy on development of economic complex]. Retrieved from: http://eprints.kname. edu.ua/30552/1/73.pdf (in Ukrainian).

Dobrovol'skaia O. P., 2007. Rehyonal'naia ekonomyka [Regional economy]. El'yn'o. Simferopol', Ukraine (in Russian).

Dovhan' H. D., 2005. Heohrafiia Ukrainy. Dovidnyk dlia peredekzamenatsijnoi pidhotovky [Geography of Ukraine. Directory for the pre-chemical preparation]. Vesta: Vyd-vo «Ranok», Kharkiv, Ukraine (in Ukrainian).

Kravtsiv V.S., 2013. Karpats'kyj rehion: aktual'ni problemy ta perspektyvy rozvytku [Carpathian region: actual problems and development prospects], NAN Ukrain: Instytut rehional'nykh doslidzhen', Kyiv, Ukraine (in Ukrainian).

Maniv Z. O., Luts'kyj I.M., Maniv S. Z., 2007. Rehional'na ekonomika [Regional economy], Mahnoliia 2006, L'viv, Ukraine (in Ukrainian).

Nahirna V. P., 2009. Terytorial'na struktura hospodarstva i rozselennia naselennia: retrospektyva i suchasni realii [Territorial structure of economy and population distribution: retrospective and modern realities]. Retrieved from: http://firearticles. com/geografiya/20-teritorialna-strukturagospodarstva-i-rozselennya-naselennyaretrospektiva-i-suchasni-realiyi-nagirna-v-p.html (in Ukrainian).

Ol'chans'ka O.V., Fachevs'kyj M.I., Bilokon' I.V., 2009, Rehional'na ekonomika [Regional economy], KNEU, Kyiv, Ukraine (in Ukrainian).

Rehional'na dopovid' pro stan navkolyshn'oho pryrodnoho sererdovyscha Zakarpats'koi oblasti [Regional re- port on the condition of the natural serfdom of the Transcarpathian region]. Retrieved from: http:// www.menr.gov.ua/docs/activity-dopovidi/regionalni/rehionalni-dopovidi-u-2015-rotsi/zakarpatska_2015.pdf (in Ukrainian).

Rehional'na dopovid' pro stan navkolyshn'oho pryrodnoho sererdovyscha u L'vivs'kij oblasti [Regional report on the state of the natural serfs in the Lviv region]. Retrieved from:http://www.menr.gov. ua/docs/activity-dopovidi/regionalni/rehionalnidopovidi-u-2015-rotsi/Lvivska 2015.pdf (in Ukrainian).

Rehional'na dopovid' pro stan navkolyshn'oho pryrodnoho sererdovyscha v Ivano-Frankivs'kij oblasti [Regional report on the state of the natural serfs in the Ivano-Frankivsk region]. Retrieved from:http:// www.menr.gov.ua/docs/activity-dopovidi/ regionalni/rehionalni-dopovidi-u-2015-rotsi/ Ivano-fr_2015.pdf (in Ukrainian).

Rehional'na dopovid' pro stan navkolyshn'oho pryrodnoho sererdovyscha v Chernivets'kij oblasti [Regional report on the condition of the natural serfs in the Chernivtsi region]. Retrieved from:http:// www.menr.gov.ua/docs/activity-dopovidi/ regionalni/rehionalni-dopovidi-u-2015-rotsi/ Chernivci_2015.pdf (in Ukrainian).

Statystychni dani Holovnoho upravlinnia statystyky u Zakarpats'kij oblasti [Statistical data of the Main Department of Statistics in the Transcarpathian region]. Retrieved from: http://www.uz.ukrstat. gov.ua (in Ukrainian).

Statystychni dani Holovnoho upravlinnia statystyky u Ivano-Frankivs'kij oblasti [Statistics of the Main Department of Statistics in Ivano-Frankivsk Oblast]. Retrieved from:http://www.ifstat.gov.ua (in Ukrainian).

Statystychni dani Holovnoho upravlinnia statystyky u L'vivs'kij oblasti [Statistical data of the Main Department of Statistics in Lviv Oblast]. Retrieved from:http://www.lv.ukrstat.gov.ua (in Ukrainian).

Statystychni dani Holovnoho upravlinnia statystyky u Chernviets'kij oblasti [Statistics of the Main Department of Statistics in Chernivetska oblast]. Retrieved from:http://www.cv.ukrstat.gov.ua (in Ukrainian).

Chakhraiuk-Onofrej S.I., Lakusta H.Iu., 2011, Problemy ta perspektyvy kompleksnoho rozvytku ekonomiky Karpats'koho rehionu [Problems and perspectives of the complex development of the economy of the Carpathian region]. Retrieved from: http:// www.rusnauka.com/13 NMN 2011/Economics/13_86485.doc.htm (in Ukrainian). 